\title{
In vitro Evolution of Different New Fungicides against the Purple Blotch of Onion Alternaria porri
}

\author{
P. P. Khandagale ${ }^{1 *}$, N. S. Ugle ${ }^{2}$, B. S. Arote And A. M. Bhosale $^{4}$ \\ ${ }^{1}$ Agricultural Research Station, Niphad, Dist.-Nasik, M.S., India \\ ${ }^{2}$ Department of Agronomy, AICRP on I.F.S., M.P.K.V., Rahuri, Dist.-Ahemadnagar, \\ M.S., India \\ ${ }^{3}$ R.B.N.B., Senior college, Shrirampur, Dist.-Ahemadnagar, M.S., India \\ ${ }^{4}$ Department of Botany and Biotechnology, P.V.P. College, Loni, Tal. Rahata, \\ Dist.-Ahemadnagar, M.S., India \\ *Corresponding author
}

\section{A B S T R A C T}

\section{Keywords}

Onion purple

blotch, fungicides,

different

concentrations,

Alternaria porri

Article Info

Accepted:

12 April 2021

Available Online:

10 May 2021
Onion is the one of the most important and oldest vegetables, culinary commodities grown in India for more than 5000 years ago. They can be eaten raw, cooked, fried, dried or roasted. No Indian food is complete without onion, although a little percentage of people does not eat these on religious grounds. Onion (Allium cepa L.) rightly called as "queen of kitchen". Purple blotch is one of the major foliar diseases having more than $90 \%$ loss in yield. Ten different fungicides were tested in vitro at different concentration against the pathogen which was isolated from diseased onion leaf. Out of which, kavach (Cholorothionil) at $0.5 \%$ concentration with $67.70 \%$ inhibition, Dithan M $45 @ 0.25 \%$ con. shows $77.35 \%$ inhibition of pathogen, biltox (Copper Oxy Chloride) at $0.1 \%$ concentration showing inhibition of pathogen as $86.47 \%$. While other concentration as $0.2 \%(90.82 \%), 0.3 \%(92.00 \%), 0.4 \%(92.70 \%)$ and $0.5 \%(93.41 \%)$. Recommended that Kavach and Dithan M-45 was use at higher concentration to manage the pathogen. In contrast to that the systemic fungicides like Score maximum inhibition were found @ $0.1 \%$ concentration as $91.52 \%$. Nativo@0.1\%concentration having inhibition as $98.52 \%$. In Signet at $0.1 \%$ concentration as $99.11 \%$. In opera at $0.1 \%$ concentration as $99.11 \%$ inhibition. Amister top at $0.1 \%$ concentration as $97.35 \%$ inhibition of pathogen. Tilt(Propiconazole 25Ec) fungicides, Where maximum inhibition were found at $0.1 \%$ concentration as $98.52 \%$.

\section{Introduction}

The onion plant (Allium cepa) also known as the bulb onion or common onion, is the most widely cultivated species of the genus Allium.
It was first officially described by Carl Linnaeus in his 1753 work Species Plantarum. Besides being used as food articles; onion has a variety of medicinal effects. It is one of the most important winter vegetable crops of 
India. It is a nutritious vegetable and contains a good amount of Vitamin $\mathrm{A}$ and $\mathrm{C}$, rich source of minerals (calcium, manganese and iron) and dietary fibers. The importance of these bulb crops in treating diversified ailments, viz. lowering blood sugar, cardiovascular problems, improving gastrointestinal health, fighting cholera, preventing urinary disorders, blood clot etc. is well recognized.

The onion, according to National Onion Association USA, (1918) the primary center of origin onion lies in Central Asia, Iran and somewhere in Pakistan. In India the crop was grown in kharif and rabi. Main crop is in rabi (50-60\%), and kharif and late kharif contributes remaining about 20-25\% each. Maharashtra, Karnataka, Gujarat, Bihar, Madhya Pradesh, Rajasthan, Andhra Pradesh and Tamil Nadu are the main onion growing states in India. In general, barring North Eastern states and Kerala, all other states grow onion. Country's 24\% area and 27\% production alone come from Maharashtra. The productivity in late kharif and rabi is around 25 tonnes per hectare, whereas in kharif season it is 8-10 tonnes per hectare.

Although India stood second in onion production after China at world level, India is far behind in productivity compared to many countries. The average productivity of onion in India in the past decade stood at only 13.78 t/ha, which is lower than world average of 18.75 t/ha (FAO Stat., 2013).

Through the crop grown in kharif and rabbi season in India, their diversified farming having many constraints as abiotic and biotic stress, unavailability of true to type seeds, irrigation in summer and rabbi season, attack of pests like aphides, jassides, thrips, whitefly and nematodes. The most important factors responsible for lower yield are the diseases like purple blotch, downy mildew, stemphylium blight, basal rot and storage rots etc., non-availability of varieties resistant to biotic and abiotic stresses.

Among the foliar diseases, purple blotch is one of the most destructive diseases, commonly prevailing in almost all onion growing pockets of the India. The name purple blotch for this disease was proposed by Nolla (1927). He named the causal organism as Alternaria allil which was later amended to Alternaria porri. The yield loss of onion in India due to this disease under favorable conditions varies from 5.0-96.5 percent (Gupta et al., 1994). Older leaves tend to be more susceptible to purple blotch than younger leaves. Symptoms begin as watersoaked lesions that usually have a white center. Edges of lesions become brown to purple and the leaf turns yellow above and below the lesions. With time, dark brown to black concentric rings form throughout the lesions. On infected leaves small, sunken, oval to foot-ball shaped lesions were found. The lesions are brown to purple at the centre surrounded by a light brown area. Concentric light and dark zones are also observed on the infected leaves. Brown lesions with reddishpurple margins resembling bull's-eye were also noticed. These are areas of sporulation and penetration of the fungus (Agale et al., 2015)(Fahim 1966)(carrol and carroll 1971).

The influence of environment on incidence of disease was studied by some workers from different part of countries and reported that high rainfall and high humidity favoured the disease development. Alternaria porri on onion occurred following a long period relative humidity $>90 \%$ or dew deposition and temperature ranges between 20-250C (Gupta and Pathak, 1986; Evert and Lacy, 1996)In our study we use different new and commercial ten fungicides against the pathogen at different concentration so that we fulfill the today's farmers need. 


\section{Materials and Methods}

\section{Collection of diseased samples}

Onion leaves infected with Alternaria purple blotch were collected from the infected leaf of the onion with typical spot symptoms.

The infected leaves were collected from A.R.S., Niphad, Dist. Nasik onion field in kharif 2020.Based on symptoms, microscopic examination of diseased samples association of the pathogen as Alternaria porri was recorded.

\section{Glassware, plastic ware and other materials}

Petri plates, glass petri dishes, conical flasks, test tubes, blotter paper and roll paper towel were used in the present studies.

\section{Method adopted}

Potato dextrose agar (PDA) medium was used for isolation and maintenance of cultures.

\section{Disinfection /sterilization of laboratory materials}

To detect the fungi on leaves, the plates were washed with cleaning powder under running water, dried and then disinfected with denatured spirit. However, glass plates were sterilized in hot air oven at $180^{\circ} \mathrm{C}$ for $1 \mathrm{hr}$. before use.

\section{Isolation of pathogen by tissue isolation method}

Infected leaf samples were cut into small pieces with sterilized blade and disinfected with sodium hypochloride $(0.2 \%)$ solution for two minute. Pieces were washed with three changes of sterilized distilled water and bits after dried on sterilized filter paper and around flame of spirit lamp were placed on solidified PDA medium in plate. Each plate contained five bits. The plates were incubated at room temperature $(28 \pm 20 \mathrm{C})$. All these operations were carried out aseptically. The plates were examined regularly. Colonies were developed around the each bit were examined and sub cultured. Based on morphological characters and published literature the fungus was identified as Alternaria porri. The pure culture was transferred on PDA slants and maintained for further studies.

\section{Purification and maintenance of fungal culture}

Culture was purified by following hyphal tip method (Vincent, 1927) and culture obtained was maintained on potato dextrose agar (PDA) medium slants at room temperature by adopting subsequent subculturing at periodical, regular intervals. Seven days old culture was used for further studies.

\section{Pathogenicity test by spray inoculation method}

We identified the pathogen as young hyphae were hyaline, slender, radiating and septate. The white colonies turned purple to black color with advancing age of culture. The conidiophores arose singly or in groups and were pale brown, erect, simple, cylindrical, septate.

Conidia were thick, solitary, straight or curved with the body of conidium ellipsoidal tapering to the beak and having 7 to 9 transverse septa and 1 to 3 longitudinal septa (Evert and Lacy 1987), (Campbell 1969).

Pathogenocity was also studied as pathogen was incubated in PDA broth for 7 days at 28 +- 2 OC. Where the pathogen attained the CFU count of $1 * 108$ were used for testing of pathogen city after spraying them on healthy plant after 10-15 days and found same symptoms as the diseased specimen shows. 
In vitro preparation of different fungicides at different concentrations

In, In vitro study commercial chemical fungicides are used as Score, Dithan M 45, Tilt, folicure, Kavch, Copper oxy chloride, Opera, Signet, Nativo, Amister top at different concentration as $0.1 @ 0.2 \% 0.3 \%$. 0.4\% and $0.5 \%$. Sterile water was used to prepare the stock solution add them in sterile PDA medium at different concentration. They grow with the control without fungicides incubate it take observation at seven day. The experiment was conducted in randomized block design (RBD) with four replications in five treatments at Deptt. of Plant Pathology, Agricultural Research Station, Niphad, Dist. Nasik(M.S.). The inoculated Petri dishes were incubated at room temperature $28^{\circ} \mathrm{C}+-2^{\circ} \mathrm{C}$ in the laboratory. The poisoned food technique was adopted for in vitro testing of fungicides (Nene and Thapliyal, 1979). The colony diameters were measured after 7 days when the control plates were full of fungal growth. Percent inhibition of growth was calculated using the formula given by Vincent (1927).

$\mathrm{I}=100 /(\mathrm{C}-\mathrm{T}) * \mathrm{C}$

Where,

$\mathrm{I}=$ per cent inhibition of mycelium growth (\%)

$\mathrm{C}=$ Growth of mycelium in control $(\mathrm{cm}$.

$\mathrm{T}=$ Growth of mycelium in treatment i.e. control (cm.)

\section{Results and Discussion}

The Dithan M 45 (Mancozeb)is the contact fungicide. Where, maximum inhibition was found significantly at $0.25 \%$ con. as $77.35 \%$. While other concentration shows the result as $0.20 \%(62.64 \%), \quad 0.15 \%(62.94 \%)$,
$0.10 \%(37.61 \%)$ and minimum inhibition were found in $0.05 \%(30.94 \%)$.

In vitro evaluation of Tilt (Propiconazole $25 \mathrm{Ec})$ fungicides the systemic fungicide. Where maximum inhibition were found significantly at $0.1 \%$ concentration as $98.52 \%$.

Folicure (Tabuconazole 250 Ec) @ $0.1 \%$ concentration where maximum inhibition were found significantly at $0.1 \%$ concentration as $97.35 \%$. While other concentration as $0.2 \%(99.70 \%), 0.3 \%(99.11 \%), 0.4 \%(99.11 \%)$ a nd $0.5 \%(100 \%)$.

Amister top is the systemic fungicide. where maximum inhibition were found significantly at $0.1 \%$ concentration as $97.35 \%$. In Opera shows maximum inhibition were found significantly at $0.1 \%$ concentration as $99.11 \%$.

In signet where maximum inhibition were found significantly at $0.1 \%$ concentration as 99.11\%. Nativo@0.1\% concentration having inhibition as $98.52 \%$. In contrast to that the systemic fungicides like Score maximum inhibition were found significantly@ 0.1\% concentration as $91.52 \%$. While other concentration as $0.2 \% \quad(95.88 \%), \quad 0.3 \%$ $(97.66 \%), 0.4 \%(100 \%)$ and $0.5 \%(100 \%)$. In biltox (Copper Oxy Chloride) the contact fungicides where different inhibition were found significantly at $0.1 \%$ concentration as $86.47 \%$. While other concentration as $0.2 \%$ (90.82\%), 0.3\%(92.00\%), $0.4 \%(92.70 \%)$ and $0.5 \%(93.41 \%)$.

The Chlorothionil (kavach) where different inhibition were found significantly as at $0.1 \%$ concentration $50.94 \%$. While other concentration as $0.2 \% \quad(53.88 \%), \quad 0.3 \%$ $(56.11 \%), 0.4 \%(62.70 \%)$ and $0.5 \%(67.70 \%)$. Recommended that Biltox, Kavach and Dithan M-45 were use at higher concentration. Same tune was found in Bhandeker et al.,(2019); Deepti and Nidhi (2015) study. 
Table.1 Area and Production of onion in India(NHB, Database)

\begin{tabular}{|c|c|c|c|c|}
\hline Year & 2016-17 & 2017-18 & 2018-19 & 2019-20 \\
\hline \multirow{2}{*}{$\begin{array}{c}\text { Area } \\
\text { Production }\end{array}$} & 1306000 ha. & 1285000 ha. & 1220000 ha. & 1293000 ha. \\
\hline & 22427000 tonne & 23265000 tonne & 22810000 tonne & 24454000 tonne \\
\hline \multicolumn{5}{|c|}{ NHB, Database Indian Horticulture } \\
\hline $\begin{array}{l}\text { Productivity } \\
(2012-13)\end{array}$ & 17.92MS & $24.09 \mathrm{MP}$ & 24.42 Guj. & \\
\hline
\end{tabular}

Table.2 Share of Different Indian states in onion production

\begin{tabular}{|c|c|c|c|}
\hline Sr.No. & State name & $\begin{array}{c}\text { Production } \\
\text { /000 tonne }\end{array}$ & Share \% \\
\hline $\mathbf{1 .}$ & Maharashtra & 9099 & 37.20 \\
\hline $\mathbf{2 .}$ & Madya Pradesh & 3966 & 16.2 \\
\hline $\mathbf{3 .}$ & Karnataka & 2275 & 9.3 \\
\hline $\mathbf{4 .}$ & Rajastan & 1386 & 5.7 \\
\hline $\mathbf{5 .}$ & Bihar & 1312 & 5.4 \\
\hline $\mathbf{6 .}$ & Gujrath & 1256.80 & 5.1 \\
\hline \multicolumn{4}{|r|}{} \\
\hline
\end{tabular}

Graph.1 Dithan M45 fungicides at different concentration reaction against the pathogen

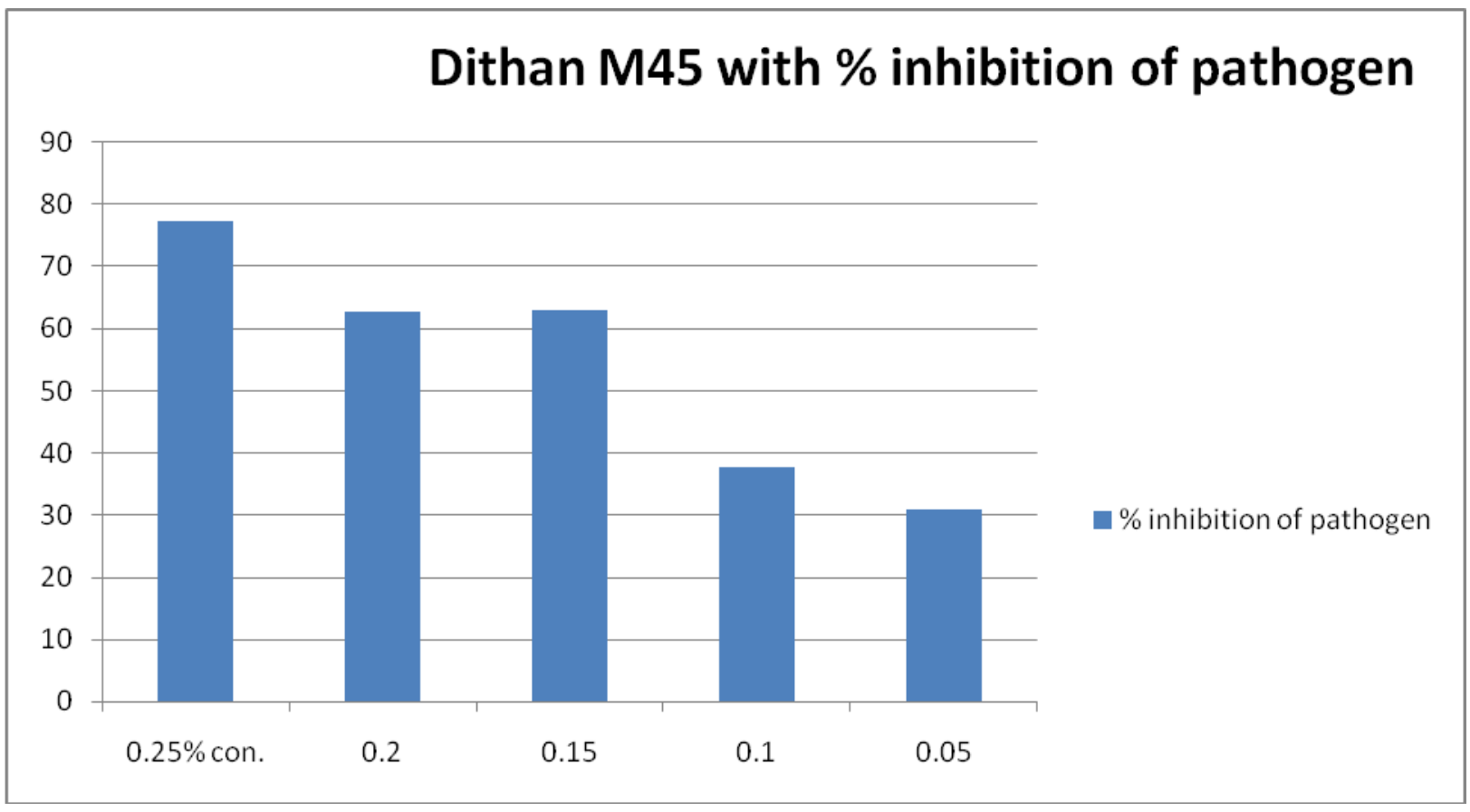


Table.3 In vitro evaluation of Dithan M 45 at different concentration against the pathogen

\begin{tabular}{|c|c|c|}
\hline Concentrations \% of Dithan M 45 & \% inhibition of pathogen & Control growth \\
\hline 0.25 & 77.35 & $8.5 \mathrm{~cm}$ \\
\hline 0.20 & 62.64 & \multirow{4}{*}{$\begin{array}{c}\mathrm{CD} @ 5 \%=0.57 \\
\mathrm{SEd}=0.26 \\
\text { significant }\end{array}$} \\
\hline 0.15 & 62.94 & \\
\hline 0.10 & 37.61 & \\
\hline 0.05 & 30.94 & \\
\hline
\end{tabular}

Table.4 In vitro evaluation of Different fungicides at different concentration against the pathogen

\begin{tabular}{|c|c|c|c|c|c|c|c|c|}
\hline \multirow{2}{*}{$\begin{array}{c}\text { Sr } \\
\text { No } \\
.\end{array}$} & \multirow{2}{*}{\multicolumn{2}{|c|}{ Name of the fungicides }} & \multicolumn{5}{|c|}{ Concentration \% } & \multirow{3}{*}{$\begin{array}{c}\text { Other Remarks } \\
\begin{array}{c}\text { CD } @ 5 \%=0.034 \\
\text { SEd }=0.015\end{array}\end{array}$} \\
\hline & & & $0.1 \%$ & $0.2 \%$ & $0.3 \%$ & $0.4 \%$ & $0.5 \%$ & \\
\hline 1. & Tilt & $\begin{array}{l}\% \text { inhibition of } \\
\text { pathogen* }\end{array}$ & 98.52 & 99.70 & 100 & 100 & 100 & \\
\hline 2. & $\begin{array}{c}\text { Folicure } \\
\text { (Tabuconazole } \\
250 \mathrm{Ec} \text { ) }\end{array}$ & $-/ /-$ & 99.11 & 99.70 & 100 & 100 & 100 & $\begin{array}{c}\mathrm{CD} @ 5 \%=0.035 \\
\mathrm{SEd}=0.015\end{array}$ \\
\hline 3. & $\begin{array}{c}\text { Amister top } \\
\text { (Azoxystrobin } \\
18.2 \% \mathrm{w} / \mathrm{w}+ \\
\text { Difenconazole } \\
11.4 \% \mathrm{Sc}\end{array}$ & $-/ /-$ & 97.35 & 99.11 & 99.70 & 99.81 & 100 & $\begin{array}{c}\mathrm{CD} @ 5 \%=0.034 \\
\mathrm{SEd}=0.015\end{array}$ \\
\hline 4. & Opera & $-/ /-$ & 99.11 & 99.70 & 100 & 100 & 100 & $\begin{array}{c}\mathrm{CD} @ 5 \%=0.0345 \\
\mathrm{SEd}=0.016\end{array}$ \\
\hline 5. & Signet & $-/ /-$ & 99.11 & 100 & 100 & 100 & 100 & $\begin{array}{c}\mathrm{CD} @ 5 \%=0.050 \\
\mathrm{SEd}=0.022\end{array}$ \\
\hline 6. & Nativo & $-1 /-$ & 98.52 & 99.11 & 99.11 & 100 & 100 & $\begin{array}{c}\mathrm{CD} @ 5 \%=0.056 \\
\mathrm{SEd}=0.025\end{array}$ \\
\hline 7. & Score & $-/ /-$ & 91.52 & 95.86 & 97.66 & 100 & 100 & $\begin{array}{c}\mathrm{CD} @ 5 \%=0.050 \\
\mathrm{SEd}=0.023\end{array}$ \\
\hline 8. & Biltox & $-1 /-$ & 86.47 & 90.82 & 92.00 & 92.70 & 93.41 & $\begin{array}{c}\mathrm{CD} @ 5 \%=0.041 \\
\mathrm{SEd}=0.018\end{array}$ \\
\hline 9. & Kavach & $-/ /-$ & 50.94 & 53.88 & 56.11 & 62.70 & 67.70 & $\begin{array}{c}\mathrm{CD} @ 5 \%=0.065 \\
\mathrm{SEd}=0.029\end{array}$ \\
\hline
\end{tabular}

In experiment \% inhibition of pathogen* is figure with 4 replication mean.

Growth of control plate without the fungicides was $8.5 \mathrm{~cm}$.

All reaction was statistically significant. 
Graph.2 In vitro evaluation of Different fungicides at different concentration against the pathogen

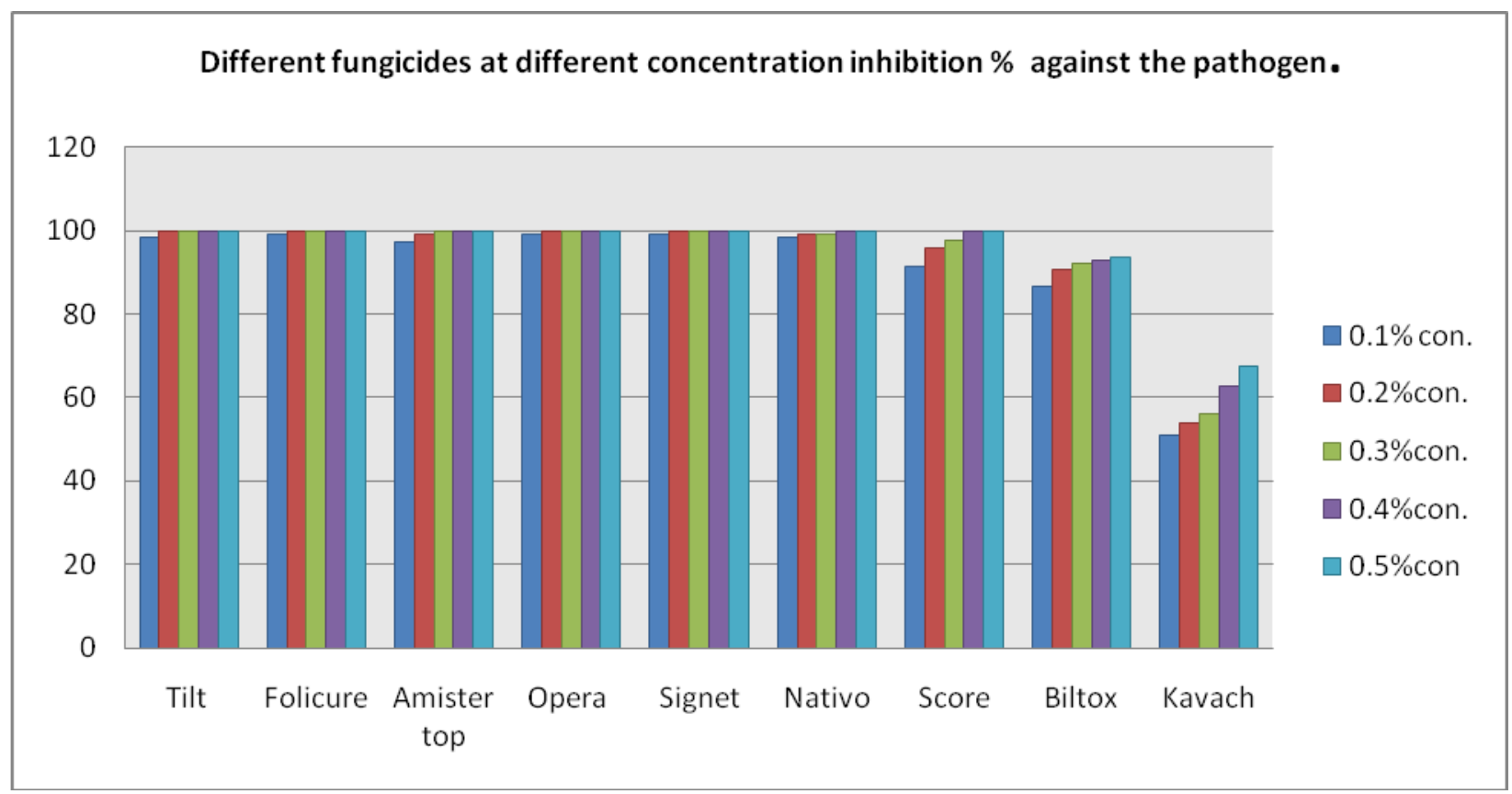

All ten fungicides tested against the pathogen out of which, kavach (Cholorothionil) at $0.5 \%$ concentration with 67.70\%inhibition, Dithan M $45 @ 0.25 \%$ con. shows $77.35 \%$ inhibition of pathogen, Biltox (Copper Oxy Chloride $50 \% \mathrm{WP})$ at $0.1 \%$ concentration showing inhibition of pathogen as $86.47 \%$. While other concentration as $0.2 \% \quad(90.82 \%), \quad 0.3 \%$ (92.00\%), $0.4 \%(92.70 \%)$ and $0.5 \%(93.41 \%)$.

Recommended that Kavach and Dithan M-45 was use at higher concentration to manage the pathogen Same tune was found in Rahman et al.,(1988), Chethana, B.S., (2000), Patel et al., (2001), Pandey et al., (2002) where Mancozeb @ $0.3 \%$ was highly effective followed by blitox and benlate and gradual reduction in fungal growth was found as the concentrations of the fungicides increased from 10 to 500 ppm. in different alterneria species management.

In contrast to that the systemic fungicides like Score (Difenconazole $25 \%$ Ec) maximum inhibition were found @ $0.1 \%$ concentration as $91.52 \%$. Nativo (Tabeconazole $50 \%+$ Trifloxystrobine 25\%WG) @ $0.1 \%$ concentration having inhibition as $98.52 \%$.In Signet (Picoxystrobin $7.05 \%$ +Propiconazole $11.7 \mathrm{Sc}$ ) at $0.1 \%$ concentration as $99.11 \%$. In Folicure (Tabuconazole 250 Ec)@0.1\% concentration where maximum inhibition were found significantly at $0.1 \%$ concentration as 97.35\%.In opera (Pyraclostrobin 133g + Epoxiconazole $50 \mathrm{~g} / \mathrm{l} \mathrm{w} / \mathrm{v})$ at $0.1 \%$ concentration as $99.11 \%$ inhibition.Amister top (Azoxystrobin 18.2\%w/w+ Difenconazole $11.4 \% \mathrm{Sc}$ ) at $0.1 \%$ concentration as $97.35 \%$ inhibition of pathogen. Tilt (Propiconazole $25 \mathrm{Ec})$ fungicides, Where maximum inhibition were found at $0.1 \%$ concentration as $98.52 \%$ (Dinesh Kumar et al., 2020). Same report from Roshan kumar et al.,(2020), where in the management of A.altenata of tomato at different fungicides in vitro and in field conditions found that tilt @300ppm,Nativo @500ppm, Amister @ 300ppm showing $100 \%$ inhibition of the pathogen. 


\section{References}

Agale R. C., Kadam J. J., Rite S. C., Kadam J. S., and Pawaskar J. R., 2015. Physiological studies on Alternaria porri causing purple blotch of White onion. Journal of Plant Disease Sciences. 9(2): 202-208.

Bhandekar, P. D., V. S. More and Aware, R. G. 2019. Efficiency of Biocontrol Agents, Botanicals and Chemical against Alternaria porri. Int.J.Curr.Microbiol.App.Sci. $\quad 8(02)$ : 384-391

Campbell, R. 1969. An electron microscope study of spore structure and development in Alternaria brassicicola. J. Gen. Microbiol. 54:381-392.

Carroll, F. E., and Carroll, G. C. 1971. Fl'ne structural studies on "poroconidium" formation in Stemphylium botryosum. In Taxonomy of Fungi Imperfecti. Ed. B. Kendrick. University of Toronto Press, Toronto.J. Bot. 52:443- 446.

Chethana, B.S., 2000 Studies on Alternaria leaf blight of onion (Allium cepa L.).M.Sc. (Agri) Thesis. Univ. Agric. Sci. Dharwad (India).

Dinesh kumar, S L Godera, A K Meena, D R Kumar, 2020., Evaluation of different fungicides in the control of purple blotch [Alternaria porri (Ellis) Cif] of onion, International Journal of Chemical studies,8(6);2173-2176.

Fahim, M. M., and El-Shehedi, A. 1966. The mode of penetration of Alternaria porri into onion leaves. Trans. Br. Mycol. Soc.49:79-80.

Linnaeus, Carolus (1753). Species Plantarum (in Latin). 1. Stockholm: Laurentii Salvii. p. 262.

Deepti S. and Nidhi D. 2015. Bioefficacy of fungicides and plant extracts against Alternaria solani causing early blight of tomato. International Conference on
Plant, Marine and Environment Sciences (PMES-2015) Kunal Lumpuri (Malaysia).

Everts, K. L., and Lacy, M. L. 1987. Conidial germination, appressorial formation and infection of Al ternaria porri on onion leaves. Phytopathology 77:1761.

Everts, K. L., and Lacy, M. L. 1996. Influence of environment on conidial concentration of Alternaria porri in air and on purple blotch incidence on onion. Phytopathology 80:1 87-1391.

FAO, UNO., FAO Statistical Year Book 2013.,Economic \& Social Department, Sources as FAO STAT.http://faostat 3 fao.org/home/index/html// Download. Dated March 2015.

Gupta R. B., L and Pathak V. N., 1994. Yield losses in onions due to purple leaf blotch disease caused by Alternaria porri. Phytophylactica 20:21-23.

Gupta R. B. L., and Pathak V. N., 1986. Effect of age host, inoculums density and duration of high relative humidity on development of purple blotch of onion. Phytophylactica 18, 151-152.

Nene and Thapliyal 1993. Fungicides in Plant Disease Control. Oxford and IBH Publishing Company, Plant diseases, pp. 691.

Nolla, J. A. B. 1927. A new Alternaria disease of onions (Allium cepa). Phytopathol. 17:115-137.

National Onion Association USA (1918).,www.noas-usa.org.in.

National Horticulture Board.India,2013 and 2019. Statistical Year Book.

Patel M. J., Joshi K. R., Vala D. G.2001., In vitro screening of fungicides and bioagents against onion leaf blight pathogen Alternaria alternata. Journal of Mycology and Plant Pathology, 2001;31(1):116.

Pandey, S., Giri, K., Kumar, R., Mishra, G. and Raja Rishi, R. Nanopesticides2018.,: opportunities in 
crop protection and associated environmental risks. Proc. Natl.Acad. Sci. India Sect. B Biol. Sci. 88, 12871308 (2018)

Rahman M. L.; H. U. Ahmed; I. H. Mian. 1988., Efficacy of fungicides in controlling purple blotch of onion. Pl. Pathol., 1988, 4, 71-76

Rao, and Bellishree, K. 2013. Bioefficacy of botanicals, bioagents and fungicides I management of purple blotch disease of onion. Environment and Ecology
31(23): 947-952

Roshan kumar., Ghasolia R. P., Yadav R. K.,2020.Management of A.altenata of tomato through plant extract and different fungicides in vitro and in field conditions. International $\mathrm{J}$. Current microbial App.Sci.,2020.,9(5):514-523.

Vincent J M (1947). Distortion of fungal hyphae in the presence of certain inhibitors. Nature, 59: 85

\section{How to cite this article:}

Khandagale, P. P., N. S. Ugle, B. S. Arote and Bhosale, A. M. 2021. In vitro Evolution of Different New Fungicides against the Purple Blotch of Onion Alternaria porri. Int.J.Curr.Microbiol.App.Sci. 10(05): 86-94. doi: https://doi.org/10.20546/ijcmas.2021.1005.013 